\title{
Microsatellite markers for the common vole (Microtus arvalis) and their cross-species utility
}

\author{
Barbara Walser · Gerald Heckel
}

Received: 27 April 2007 / Accepted: 1 June 2007/Published online: 24 July 2007

(C) Springer Science+Business Media B.V. 2007

\begin{abstract}
Fragmentation of natural habitats of the common vole (Microtus arvalis) provides an excellent model system to study the consequences of restricted gene flow and small population sizes for isolated populations. Here we describe the isolation and characteristics of 10 autosomal and one X-linked microsatellite marker. These new markers were tested in 24 voles from a natural population in eastern Germany. Loci were highly polymorphic with numbers of alleles per locus ranging from three to 26 and expected heterozygosities from 0.51 to 0.97 . All loci except for the X-linked locus Mar105 followed Hardy-Weinberg expectations. Cross-species amplifications revealed that most loci were polymorphic as well in M. agrestis, M. thomasi, and M. pennsylvanicus.
\end{abstract}

Keywords Microtus - Genetic markers - Microsatellites · Short tandem repeats $\cdot$ STR

The common vole, Microtus arvalis, is a small rodent, which plays due to its abundance a prominent role in many open habitats in temperate Europe. The species has a continuous range from the Atlantic coast of France to the Ukraine and Russia, and it is not yet well understood if eastern populations form separate species (Fink et al. 2004; Mitchell-Jones et al. 1999). European populations are genetically highly differentiated due to the limited dispersal abilities (Heckel et al. 2005). On a smaller scale, the fragmentation of habitats through modern agricultural practices provides an excellent model system to study the effects of restricted gene

B. Walser · G. Heckel ( $\square)$

Computational and Molecular Population Genetics (CMPG),

Zoological Institute, University of Bern, Baltzerstrasse 6, Bern

3012, Switzerland

e-mail: gerald.heckel@zoo.unibe.ch flow, small effective sizes and inbreeding on isolated populations (see Schweizer et al. 2007). In this study, we describe the isolation of 10 autosomal and one X-linked microsatellite locus of $M$. arvalis and their utility in crossspecies amplification with the European species $M$. agrestis, M. thomasi and the American M. pennsylvanicus.

Microsatellites were isolated following the enrichment protocols by Glenn and Schable (2005) with slight modifications as follows. A genomic library was constructed with DNA $(\approx 140 \mu \mathrm{g} / \mu \mathrm{l})$ isolated from muscle tissue of a $M$. arvalis individual from a population near Belp, Switzerland $\left(46^{\circ} 55^{\prime} \mathrm{N}, 7^{\circ} 29^{\prime} \mathrm{E}\right)$. DNA was digested with Rsa I and fragments of approximately $500 \mathrm{bp}$ were screened for microsatellite sequences with a mixture of the five probes $(\mathrm{TG})_{12},(\mathrm{GA})_{15},(\mathrm{AATC})_{6},(\mathrm{AATG})_{6}$ and $(\mathrm{ATTG})_{6}$. For cloning of vole DNA, we used the Qiagen PCR Cloning ${ }^{\text {plus }}$ Kit. 136 of approximately 695 colonies contained positively hybridizing clones. We used M13 primers and $1.5 \mu \mathrm{l}$ of bacterial pellet for PCR-amplification of the region containing the microsatellite sequences in a reaction volume of $25 \mu \mathrm{l}$ on a GeneAmP® PCR system 9700 (Applied Biosystems) according to Glenn and Schable (2005). PCRproducts were separated on $1 \%$ agarose gel, length differences were scored by comparison with a 100 bp ladder (Invitrogen), and PCR-products were purified for sequencing with GenElute ${ }^{\mathrm{TM}}$ PCR Clean-Up-Kit (Sigma). Vole DNA inserts were sequenced with the Terminator Ready Reaction Mix 'Big Dye' Version 3.1 from Applied Biosystems in a reaction volume of $10 \mu$ following the recommendations of the manufacturer. The sequencing products were precipitated, and separated and detected on an ABI Prism 3100 Genetic Analyser from Applied Biosystems.

PCR-primers based on the clone sequences were designed using Primer3 (Rozen and Skaletsky 2000). PCR 


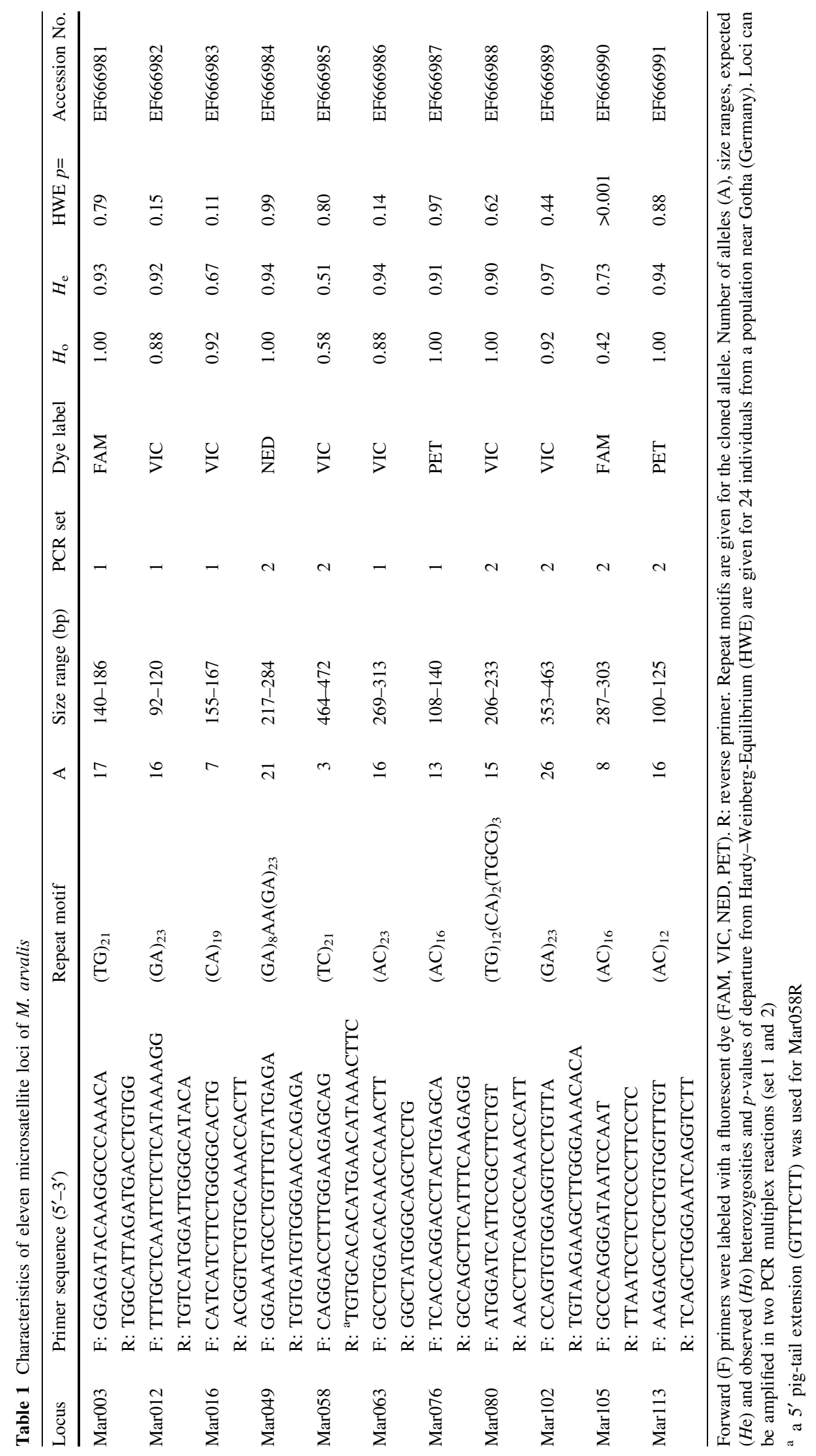


Table 2 Results of cross-species amplifications with the newly developed primers for the two European species M. agrestis and M. thomasi and the American species M. pennsylvanicus

\begin{tabular}{llll}
\hline Locus & M. agrestis & M. thomasi & M. pennsylvanicus \\
\hline Mar003 & $\mathrm{p}$ & $\mathrm{p}$ & - \\
Mar012 & - & $\mathrm{p}$ & - \\
Mar016 & $\mathrm{p}$ & $\mathrm{m}$ & $\mathrm{p}$ \\
Mar049 & $\mathrm{p}$ & $\mathrm{p}$ & $\mathrm{p}$ \\
Mar058 & - & - & - \\
Mar063 & $\mathrm{p}$ & $\mathrm{p}$ & $\mathrm{p}$ \\
Mar076 & - & $\mathrm{p}$ & $\mathrm{p}$ \\
Mar080 & $\mathrm{p}$ & $\mathrm{p}$ & $\mathrm{p}$ \\
Mar102 & - & - & - \\
Mar105 & - & - & - \\
Mar113 & $\mathrm{p}$ & - & $\mathrm{p}$ \\
\hline
\end{tabular}

p: polymorphic; m: monomorphic; -: no amplification

amplifications of microsatellite loci were carried out in two sets of five and six loci each using the Qiagen multiplex PCR kit (Table 1). Amplifications were done in $10 \mu \mathrm{l}$ reaction volumes following otherwise the recommendations of the manufacturer. Fragment separation was done by electrophoresis on an ABI Prism 3100 Genetic Analyser (Applied Biosystems), and fragment length was determined in comparison to an internal standard (GeneScan $^{\mathrm{TM}}$ 500 LIZ $^{\mathrm{TM}}$, Applied Biosystems) using Genemapper software version 3.7 (Applied Biosystems).

Variability at the loci was tested with 24 samples from a $M$. arvalis population from Gotha, Germany $\left(50^{\circ} 59^{\prime} \mathrm{N}\right.$, $\left.10^{\circ} 41^{\prime} \mathrm{E}\right)$. Numbers of alleles per locus, fragment sizes, and observed and expected heterozygosities are listed in Table 1. Statistical tests with Arlequin 3.1 (Excoffier et al. 2005) provided no significant evidence for linkage disequilibrium among loci and no significant deviations from Hardy-Weinberg expectations except for locus Mar105 $(p<0.001)$. Closer inspection of the data revealed that all males in the population were apparently homozygous whereas 10 out of 12 females were heterozygous at this locus which strongly suggests X-chromosomal linkage.

We evaluated cross species amplification in two European and one American Microtus species: M. agrestis
$(N=4)$, M. thomasi $(N=4)$, M. pennsylvanicus $(N=2)$. Most loci were amplified successfully in several species, and only Mar058, Mar102, and Mar105 could not be amplified in any other species than M. arvalis (Table 2). Polymorphisms were detected in most species even though cross species tests were performed with only a few samples. This suggests that at least some of these new markers could be applied to a wide variety of species within the genus Microtus. The markers are currently being employed in studies of dispersal and reproductive success in natural and experimental populations (Fink et al. 2006).

Acknowledgements Thanks go to Sabine Fink, Jörg Hahne and Susanne Tellenbach for technical assistance. Support by the Stiftung zur Förderung der wissenschaftlichen Forschung an der Universität Bern is gratefully acknowledged. This work was funded in part by Swiss National Science Foundation grant 3100A0-112072.

\section{References}

Excoffier L, Laval G, Schneider S (2005) Arlequin ver. 3.0: An integrated software package for population genetics data analysis. Evol Bioinform 1:47-50

Fink S, Excoffier L, Heckel G (2004) Mitochondrial gene diversity in the common vole Microtus arvalis shaped by historical divergence and local adaptations. Mol Ecol 13:3501-3514

Fink S, Excoffier L, Heckel G (2006) Mammalian monogamy is not controlled by a single gene. Proc Natl Acad Sci USA 103: 10956-10960

Glenn TC, Schable NA (2005) Isolating microsatellite DNA loci. Meth Enzymol 395:202-222

Heckel G, Burri R, Fink S, Desmet J-F, Excoffier L (2005) Genetic structure and colonization processes in European populations of the common vole Microtus arvalis. Evolution 59:2231-2242

Mitchell-Jones AJ, Amori G, Bogdanowicz W, Krystufek B, Reijnders PJH, Spitzenberger F, Stubbe M, Thissen JBM, Vohralik V, Zima J (1999) The atlas of European mammals. T. Poyser, A.D. Poyser, London

Rozen S, Skaletsky H (2000) Primer3 on the WWW for general users and for biologist programmers. In: Krawetz S, Misener S (eds) Bioinformatics methods and protocols: methods in molecular biology. Humana Press, Totowa, NJ, pp 365-386

Schweizer M, Excoffier L, Heckel G (2007) Fine-scale genetic structure and dispersal patterns in the common vole Microtus arvalis. Mol Ecol 16:2463-2473 